\title{
Economic Valuation of River Conservation towards International Tourists' Preferences and Willingness to Pay for Ecofriendly Services of Hotel Industry: A Case Study of Namxong River in Vangvieng District, Laos
}

\author{
Phouthivong Khamsay, Yoshifumi Takahashi, Hisako Nomura, Mitsuyasu Yabe* \\ Laboratory of Environmental Economics, Division of International Agricultural and Resource Economics and \\ Business Administration, Department of Agricultural and Resource Economics, Faculty of Agriculture, Kyushu \\ University, Fukuoka, Japan \\ Email: *yabe@agr.kyushu-u.ac.jp
}

Received 16 July 2015; accepted 16 August 2015; published 19 August 2015

Copyright (C) 2015 by authors and Scientific Research Publishing Inc.

This work is licensed under the Creative Commons Attribution International License (CC BY). http://creativecommons.org/licenses/by/4.0/

(c) (i) Open Access

\begin{abstract}
Using choice experiment, the objective of this study is to estimate international tourists' preferences and willingness to pay for ecofriendly services which related to river and natural environment conservation of hotel industry in Vangvieng, a popular tourist town in Lao PDR. We used the mixed logit to take into account of preference heterogeneity by allowing coefficients to be normally distributed and assumed to vary among individuals. The result shows that all ecofriendly practices offered in this study are significantly preferred by tourists. Income, age, and education did not have significant effect on the probability of choosing ecologically friendly practices of hotel and attributes to support the ecotourism of the area; however, this study provides important information that female tourists are more receptive to a new alternative. These findings do not only support the provision of good and green services in Vangvieng Town, but will also be useful for policy maker to enhance the sustainability of ecotourism in Laos.
\end{abstract}

\section{Keywords}

Choice Experiment, Ecofriendly Service, Ecotourism, Hotel Industry, International Tourist, River

\footnotetext{
${ }^{*}$ Corresponding author.
} 


\section{Introduction}

Rivers play a key role in ecosystems and society, and they provide a range of ecosystem functions such as shelter and food source for an array of biological species, aid in flood management and ecological refuge development [1]. Socially, rivers accommodate communities by providing a medium for transport, recreation, tourism, worship, ecosystem services and a place to experience the serenity of nature [2].

As a land locked, but rich with natural and fresh water sources among the Lower Mekong Basin countries, Lao PDR has great potential for tourism industrial development, especially for natural resource and river basedecotourism [3]. In 2013 it was reported that among 1916 tourist attractions nationwide, 1093 places were accounted as natural sites and tourism became the second main source of export income after mining sector [4].

Covering 180,434 hectares of river basin with around $106 \mathrm{Km}$ length and flowing through larger areas of three districts, the Nam Xong River is not only important for local livelihood but the most economically beautiful and unique river for tourism in Vientiane province. Especially in Vangvieng district, where most of tourist attractions and activities are based on natural resources, Namxong River in particular [5], the growth of tourism has been significantly outstanding in recent years. While only 4468 tourist arrivals were reported in 1997, the number had increased continuously and reached 167,444 visitors in 2013, given that $70 \%$ of them were from foreign countries [6]. This result inevitably pushed tourist accommodation to increase from only1 hotel and 52 guesthouses in 2006 to 13 hotels and 120 guesthouses, bungalows and resorts in 2013 and it was reported that more than $60 \%$ of district income was from tourism [6].

Nevertheless, some challenges for sustainable tourism development are still concerned. The rapid growth of tourism industry is expected to exert an ever great pressure on the environment, society and culture. The lack of direct participation of communities, financial constraints and limited access to credit for conservation are the key challenges facing sustainable ecotourism development [7]. In towns heavily reliant on tourism, some negative bio-physical impacts were evident including increased pressure on water supply and drainage, wastewater from tourist facilities and restaurant discharged directly into the rivers [8].

In Vangvieng, it has been disputed that rapid urban development is detrimental on natural environment, and remedial action is required [8]. Chronically fiscal deficit of the country may cause the public revenue generated from this tourist town inappropriately comes back to fund its environmental conservation programs for this Nam Xong River and consequently most of conservation programs conducted in the watershed of this river is dependent on oversea donation. In addition, poor quality of services with low price in hotel industry may cause the lack of participation of accommodation providers in caring of the environment program [9].

In spite of the partnership between national protected area (NPA) managers, local communities and private sectors in provision of good and green services in tourist sites has been promoted [7] and participation of accommodation providers in caring for the environment program has been recommended [9]; a study that provides appropriate information about tourism market demand for these good and green services has still been hard to find, especially in this tourist town. Therefore, these products have not been systematically supplied.

On the other views, while at least 29 green attributes mentioned by Environmentally Friendly Hotels [10], a few attributes are commonly applied in a survey of market demand [11]-[13]. Kang et al. [14] suggests that the level of willingness to pay may be different from one kind of green practice from another, so investigating their intention to pay for each individual green initiative may be meaningful; and it may be interesting to analyze environmental sensitivity of travellers based on their destination of interest. Even though some recent studies can even identify interesting values of willingness to pay additional or premium price in term of percentage and dollar for green hotel [12]-[14]. A study using the choice experiment to find out customers' preference towards each specific green attribute is rare to cite. Only a conjoint study of Millar \& Baloglu [11] is close to the choice experiment, but no price attribute, however.

While water rate or one-off payment are often found in studies on evaluation of non-marketed values of rivers through households' willingness to pay (WTP) and preferences [15]-[19]. Several studies on economic valuation of ecosystem services have also been recently estimated to improve entrance fees and price of tour packages in even developing countries [20]-[23] or premium price for green products provided by private sector such as hotels [12].

To estimate economic value of this Nam Xong River conservation, 3 green attributes which closely link to river conservation are used in this study, including water quality conservation, local handicraft products in guestroom and responsibility for biodiversity conservation along the river. By using choice experiment, the objective 
of this study is to find out which of these ecofriendly services are preferred by international tourists. The finding is to provide more appropriate information about market demand which is important for policy maker to improve service quality of hotel industry and conservation programs in this town.

\section{Methodology}

\subsection{Choice Experiment (CE)}

$\mathrm{CE}$ is one of choice modeling technique that close links with economic theory which allow the results to be interpreted as being equal to marginal (or total) values for use in CBA [24]. The CE approach has increasingly been used to value the effects of changes in environmental attributes or policies [25]. CE is particular well suited to measuring the marginal value of the attributes of a good or policy compared to the contingent valuation (CV) [26].

According to Hensher et al., 2005, $V_{i j}$ is denoted as a deterministic utility that can be explained by the attributes in alternative $j$ in the relevant choice set as well as by the respondent $i$ 's characteristics. $\varepsilon_{i j}$ is the random error term that indicates the unknown factors about the respondent $i$ or imperfect information that cannot be explained by attributes in alternative $j$ in the choice set. The indirect utility $\left(U_{i j}\right)$ can be expressed:

$$
U_{i j}=V_{i j}+\varepsilon_{i j}
$$

Assuming that in the relevant choice set consists of $J$ alternatives $(\forall j \in j=1, \cdots, k, \cdots, J)$. The probability that the respondent $i$ prefers alternative $j$ in the choice set to any alternatives, can be expressed as following equations:

$$
\operatorname{Prob}_{i j}=\operatorname{Prob}\left[\left(U_{i j} \geq U_{i k}\right) \forall j \in j=1, \cdots, k, \cdots, J ; k \neq j\right]
$$

then

$$
\begin{aligned}
& \operatorname{Prob}_{i j}=\operatorname{Prob}\left[\left(V_{i j}+\varepsilon_{i j} \geq V_{i k}+\varepsilon_{i k}\right) \forall j \in j=1, \cdots, k, \cdots, J ; k \neq j\right] \\
& \operatorname{Prob}_{i j}=\operatorname{Prob}\left[\left(\varepsilon_{i k}-\varepsilon_{i j} \leq U_{i j}-U_{i k}\right) \forall j \in j=1, \cdots, k, \cdots, J ; k \neq j\right]
\end{aligned}
$$

where, disturbance term $(\varepsilon)$ is assumed to be independently and identically distributed (IID) with an extreme-value type 1 (EV1) distribution. The probability of the respondent $i$ choosing the alternative $j$ out of the set of $J$ alternatives equals to the ratio of the exponential of the observed utility index for alternative $j$ to the sum of the exponential of the observed utility indices for all $J$ alternatives, including the $j$ th alternative. The conditional logit (CL) model known as a specification of general multinomial logit (MNL) model can be estimated as follow:

$$
\operatorname{Prob}_{i j}=\frac{\exp V_{i j}}{\sum_{j=1}^{J} \exp V_{i k}} \quad \forall j \in j=1, \cdots, k, \cdots, J ; k \neq j
$$

The log-likelihood function is expressed in the Equation (6), where $y_{i j}$ is an indicator variable which takes a value of 1 if respondent $i$ choose alternative $j$ and zero otherwise:

$$
\log L=\sum_{j=1}^{J} \sum_{i=1}^{N} y_{i j} \log \left[\frac{\exp \left(V_{i j}\right)}{\sum_{j=1}^{J} V_{i k}}\right]
$$

However, the MNL is most commonly used in discrete choice model for the analysis of results from CEs and its relative simplicity is a clear advantage. Consequently, the restricted condition that the homogenous preference across respondents and the independence of irrelevant alternative (IIA) assumptions needs to be satisfied always entails the MNL facing some important limitation [27]. Therefore, the random parameters logit (RPL) or mixed logit model is considered to relax IIA limitation of the MNL. In comparison, the mixed logit model accounts for preference heterogeneity by allowing coefficients to be distributed and assumed to vary among individuals.

The utility associated with each alternative $j$, as evaluated by each individual $i$ in choice situation $t$, is represented in a discrete choice model by a utility expression of the general form: 


$$
U_{i j}=\beta_{i}^{\prime} X_{i j}+\varepsilon_{i j}
$$

where $X_{i j}$ is the full vector of explanatory variables that can be observed, including attributes of the alternatives, socio-economic characteristics of the individual and descriptors of the decision context and choice task itself in choice situation $t . \beta_{i}$ and $\varepsilon_{i j}$ are not observed by analyst and treated as stochastic influences. Given the value of $\beta_{i}$ and under familiar condition that $\varepsilon_{i j}$ is independent and identically distributed (IID) extreme-value type 1 across individuals, alternatives, and choice situation, the conditional probability that individual $i$ select alternative $j$ is simple logit.

$$
L_{i j}=\frac{\exp \left(\beta_{i}^{\prime} X_{i j}\right)}{\sum_{j=1}^{J} \exp \left(\beta_{i}^{\prime} X_{i k}\right)}
$$

The unconditional choice probability is the expected values of the logit probability over all the possible values of $\beta_{i}$, that is, integrated over these values, weighted by the density of $\beta_{i}\left(f\left(\beta_{i} / \theta\right)\right)$, where $\theta$ are the parameters of this distribution.

$$
P_{i j}=\int \frac{\exp \left(\beta_{i}^{\prime} X_{i j}\right)}{\sum_{j=1}^{J} \exp \left(\beta_{i}^{\prime} X_{i k}\right)} f\left(\beta_{i} / \theta\right) \mathrm{d} \beta_{i}
$$

Unlike MNL, the simulation technique of sequences needs to be applied to calculate the probability in the mixed logit model [28] [29].

\subsection{Survey Design}

The main purpose of this study is to find out an appropriate way to encourage private sector, especially hotel industry in this Vangvieng Town, to participate in sustainable natural environment conservation program by providing their guests with ecofriendly services that related to river conservation within their hotel while gaining more benefits. But a question arises to which ecofriendly or green practices are most preferred among several green attributes. According to the rapid growth in number of hotel with various sizes and prices along the river and the discussion with the natural resources and environment office of the district during pilot survey in September 2014, basic green levels of practice, such as wastewater recycling system, still strongly needs to be taken into account. Based on green attributes defined by Environmentally Friendly Hotels, 2014 [10], 3 important green attributes that close link to river conservation are selected. Firstly water quality conservation is introduced to reduce negative effect of water demand and consumption in hotel industry [30] [31], and it consists of 3 attribute levels. Secondly, given that all of which are friendly to environment and human health, the local handicraft products are intently offered in term of cotton towels, cotton bed sheets as well as furniture in hotel guestroom. This attribute is offered in order to enhance level of being green in hotel industry, while increase local people income from ecotourism. An increasing benefit from participation in ecotourism will then increase their attitudes towards conservation [21]. Thirdly, biodiversity and natural forest conservation along the river is introduced to promote an existing conservation program. The program is one of environment conservation policies of local government which requires the cooperation from local communities or local villages where located along the river and sub-river in taking responsibilities to protect an area within their village's territory. But the lack of financial support has remained the main factor confining this program. So this ecofriendly attribute of hotel is defined to promote the program by taking responsibility for conservation in a proper area and this is promoted by the local government. Finally, the price attribute is referred to an additional price or a premium price per night for each option of green services (Table 1).

Totally, 54 combinations are produced from 3 attributes each with 3 levels and 1 attribute with 2 levels $\left(3^{3} \times\right.$ $2^{1}$ ). By using SPSS software program [29], 32 combinations are yielded and divided into 6 versions with 3 alternatives in each choice set including the status quo (no any green services) (Table 2). Implying that the first four respondents receive 5 choice sets, while 6 choice sets are allocated for the last two respondents.

In this study, it is alternatively hypothesized that these ecofriendly attributes indifferently influence on the probability that tourist will choose for new service offered by hotel. Also Main socio-economic factors affect indifferently on the probability of choosing new alternative offered in choice set. 
Table 1. Ecofriendly attributes and attribute levels.

\begin{tabular}{cl}
\hline Attributes & \multicolumn{1}{c}{ Level } \\
\hline Water quality & 1) No (No conservation), \\
conservation(WQC) & 2) Wastewater recycling only (WRO), \\
Cotton towel, bed sheets and & 3) Wastewater recycling + organic soap \& amenities (WROSA). \\
furniture in guestroom (CTBF) & 1) Local handicraft products (LHP), \\
& 2) Non-local handicraft products (NLHP). \\
Biodiversity conservation along the river (BIOC) & 1) 0 ha (No conservation), \\
Additional price/night (AP) & 2) 10 ha, and \\
\hline
\end{tabular}

\begin{tabular}{|c|c|c|c|}
\hline Attributes & Option A & Option B & Option C \\
\hline Water quality conservation & $\begin{array}{l}\text { Wastewater } \\
\text { recycling only }\end{array}$ & $\begin{array}{c}\text { Wastewater recycling + Organic } \\
\text { soap set }\end{array}$ & \multirow{4}{*}{$\begin{array}{l}\text { I would not choose } \\
\text { any of these options } \\
\text { I prefer the same } \\
\text { service }\end{array}$} \\
\hline Cotton towel, bed sheets \& furniture & $\begin{array}{c}\text { Non-local handicraft } \\
\text { products }\end{array}$ & $\begin{array}{l}\text { Local handicraft } \\
\text { products }\end{array}$ & \\
\hline Biodiversity conservation & $\begin{array}{c}0 \text { ha } \\
\text { (No conservation) }\end{array}$ & $\begin{array}{l}10 \text { ha along } \\
\text { the river }\end{array}$ & \\
\hline Additional price/night & $\$ 1$ & $\$ 3$ & \\
\hline I would choose. & $\square_{1}$ & $\square_{2}$ & $\square_{3}$ \\
\hline
\end{tabular}

\subsection{Data Collection}

Face to face interview was conducted in Vangvieng Town during November, 2014. Totally, 200 international tourists from 27 countries were randomly interviewed.

Each questionnaire was divided into 4 parts. Part one, respondents were asked some introduction questions about sources of information about this tourist town, frequency of visit, inspiration to visit the town, hotel room price and length of stay; then followed by questions about agreement with the role of green products in tourist site and experiences of staying in an ecofriendly hotel. Part two, respondent was explained about each ecofriendly service that will be offered by hotel and also its relation to conservation of the river and natural environment before being asked to express their support in this part and preference by choosing the most preferred alternative offered in each choice set in part three. Finally, the information about social demographic of respondents was asked in part four.

\section{Sample Summary and Descriptive Statistics}

The largest respondents were from Europe and Asia 47\% and 37\% (Table 3), but the biggest group was from South Korea and followed by Germany, Thailand, Britain, and France. 52\% were female and 68\% were not married. Majority of respondent was still young with the age between 18 - 30 years old (66\%), and had high education level (university $72 \%$ and vocational or college $15 \%$ ). While $76 \%$ of them were employed, $17 \%$ were still university or college students. More than half or $55.5 \%$ mentioned that their annual income was higher than $\$ 20,000$ and $50 \%$ claimed they came to visit as backpacking tourists. Almost respondents, $88 \%$ mentioned that it was their first visit.

On average, respondents spent around 3 days or 2 nights visiting the town. While average value of hotel price mentioned by respondents was $\$ 14 /$ night, the cheapest and the most expensive prices were ranged only from $\$ 3 /$ nigh to $\$ 85 /$ night. Among 200 respondents only 10 of them did not complete or not answer choice questions. Therefore, 190 complete questionnaires with 1008 observations out of 3025 choice sets were used in the analysis. In this study, all variables are dummies, except only the price which is a continuous variable (Table 4). 
Table 3. Respondent's profile.

\begin{tabular}{|c|c|c|c|}
\hline \multicolumn{2}{|c|}{ Category } & \multirow{2}{*}{$\begin{array}{c}\text { Frequency } \\
94\end{array}$} & \multirow{2}{*}{$\begin{array}{c}\text { Percent } \\
47\end{array}$} \\
\hline \multirow{3}{*}{ Region } & Europe & & \\
\hline & Asia & 74 & 37 \\
\hline & Other & 32 & 26 \\
\hline \multirow{6}{*}{ Age group } & $18-25$ & 67 & 34 \\
\hline & $26-30$ & 64 & 32 \\
\hline & $31-40$ & 38 & 19 \\
\hline & $41-50$ & 12 & 6 \\
\hline & $51-60$ & 12 & 6 \\
\hline & $>60$ & 7 & 4 \\
\hline \multirow{2}{*}{ Gender } & Male & 95 & 48 \\
\hline & Female & 105 & 52 \\
\hline \multirow{3}{*}{ Marital Status } & Married & 48 & 24 \\
\hline & single & 136 & 68 \\
\hline & other & 16 & 8 \\
\hline \multirow{3}{*}{$\begin{array}{c}\text { Education } \\
\text { level }\end{array}$} & $\leq$ High school & 27 & 13.5 \\
\hline & Vocational or collage & 29 & 14.5 \\
\hline & $\geq$ University & 144 & 72 \\
\hline \multirow{4}{*}{ Occupation } & Government & 22 & 11 \\
\hline & Private & 130 & 65 \\
\hline & Student & 33 & 16.5 \\
\hline & Other & 15 & 7.5 \\
\hline \multirow{10}{*}{$\begin{array}{l}\text { Income } \\
\text { group }\end{array}$} & $<\$ 2000$ & 21 & 10.5 \\
\hline & $2000-5000$ & 16 & 8 \\
\hline & $6000-10,000$ & 20 & 10 \\
\hline & $11,000-15,000$ & 27 & 13.5 \\
\hline & $16,000-20,000$ & 5 & 2.5 \\
\hline & $21,000-30,000$ & 37 & 18.5 \\
\hline & $31,000-50,000$ & 28 & 14 \\
\hline & $51,000-70,000$ & 30 & 15 \\
\hline & $71,000-100,000$ & 12 & 6 \\
\hline & $>\$ 100,000$ & 4 & 2 \\
\hline
\end{tabular}

Data source: field survey 2014, November.

Table 4. Description of variables.

\begin{tabular}{|c|c|c|c|c|c|}
\hline Variable & Description and codification & Mean & Std & Min & Max \\
\hline ASC & $\begin{array}{c}\text { Alternative Specific Constant (ASC }=1 \text { if one of new } \\
\text { alternatives is chosen and } 0=\text { otherwise) }\end{array}$ & & & & \\
\hline WRO & $\begin{array}{l}\text { Water quality conservation by using wastewater recycling system only } \\
\text { (WRO }=1 \text { if WRO is chosen and } 0=\text { otherwise) }\end{array}$ & 0.24 & 0.43 & 0.00 & 1.00 \\
\hline WROSA & $\begin{array}{l}\text { Water quality conservation by using wastewater recycling } \\
\text { system and serving with organic soaps and amenities }\end{array}$ & 0.17 & 0.38 & 0.00 & 1.00 \\
\hline LHP & $\begin{array}{l}\text { (WROSA }=1 \text { if WROSA is chosen and } 0=\text { otherwise) } \\
\text { Cotton towels, bed sheets and furniture in guestroom made from local communities } \\
\text { (LHP }=1 \text { if LHP is chosen and } 0=\text { otherwise) }\end{array}$ & 0.34 & 0.47 & 0.00 & 1.00 \\
\hline BIOC1 & $\begin{array}{l}\text { Biodiversity conservation along the river within } 10 \text { ha } \\
\text { (BIOC1 }=1 \text { if } 10 \text { ha conservation is chosen and } 0=\text { otherwise) }\end{array}$ & 0.25 & 0.43 & 0.00 & 1.00 \\
\hline BIOC2 & $\begin{array}{l}\text { Biodiversity conservation along the river within } 20 \text { ha } \\
\text { (BIOC2 }=1 \text { if } 20 \text { ha conservation is chosen and } 0=\text { otherwise) }\end{array}$ & 0.69 & 0.37 & 0.00 & 1.00 \\
\hline \multirow[t]{2}{*}{$\mathrm{AP}$} & Additional price for hotel room per night and takes the value $\$ 0, \$ 1$, $\$ 3$ and $\$ 5$. & 1.58 & 1.93 & 0.00 & 5.00 \\
\hline & Non-attribute variable & & & & \\
\hline MALE & Gender of respondent (MALE $=1$ if male and $0=$ female) & 0.45 & 0.50 & 0.00 & 1.00 \\
\hline EUT & European tourist (EUT = 1 if European tourist, $0=$ otherwise) & 0.47 & 0.50 & 0.00 & 1.00 \\
\hline
\end{tabular}




\section{Study Result}

\subsection{Choice Experiment Result}

According to the Equation (1), the observable component of the indirect utility function can be expressed by the sum of attributes' part-worth utilities of the respondents [32]. The indirect utility function for an individual $i$ selecting an alternative $j$ at a choice situation $t$, takes the form as follow [33]:

$$
\begin{aligned}
U_{i j t}= & \beta_{1} \mathrm{WRO}_{i j t}+\beta_{2} \mathrm{WROSA}_{i j t}+\beta_{3} \mathrm{LHP}_{i j t}+\beta_{4} \mathrm{BIOC1}_{i j t} \\
& +\beta_{5} \mathrm{BIOC}_{i j t}+\beta_{6} \mathrm{AP}_{i j t}+\varepsilon_{i j t}
\end{aligned}
$$

where, $\beta_{1}$ represents the coefficient of the alternative specific constant and $\beta_{2}, \beta_{3}, \beta_{4}, \beta_{5}$ and $\beta_{6}$ denote the coefficients of attributes associated with the ecofriendly services provided by hotel that related to river conservation. $\varepsilon_{i j t}$ denotes as the error term.

Using the econometric software Nlogit Version 5 and under the assumption that coefficients across individual are constant and the choice sets comply with the IIA condition [27] [34], the results from the MNL model in column 1 shows that the coefficients of all green attribute variables are positively and highly significant level at 1\% (Table 5). It implies that all ecofriendly services of hotel industry offered in choice sets are preferred by the respondents. The coefficient of price attribute (AP) is also highly significant but negative. It suggests that when additional price increases, the probability that a new set of ecofriendly services or a new alternative provided by hotel will be chosen by the respondents will be less and vice versa when the additional price decreases. The ASC has a negative coefficient, but no conclusion is drawn due to insignificance. While both levels of WQC show the positive probability of being chosen, WROSA, the higher level of WQC, has a greater coefficient than WRO which is the lower level. It implies a new alternative with WROSA is more likely to be chosen than those with WRO. In other words, it can be described that international tourists probably concern that wastewater discharged from the hotel they are staying might be deposited in the river. In line with this concern, organic soaps and amenities are also friendly to human health and natural environment; therefore, the higher level of WQC is demanded by this tourist group.

The positively and highly significant coefficient of LHP suggests that the respondents more prefer the cotton towels, bed sheets and furniture made from local communities to those that are non-local products. This can be

\begin{tabular}{|c|c|c|c|c|}
\hline \multirow{2}{*}{ Variable } & \multicolumn{2}{|c|}{ Homogeneity } & \multicolumn{2}{|c|}{ Heterogeneity } \\
\hline & MNL & Extended MNL & Mixed Logit & Extended Mixed Logit \\
\hline ASC & $-0.159(0.197)$ & $0.176(0.256)$ & $1.759^{*}(1.048)$ & $4.210^{* *}(2.142)$ \\
\hline WRO & $1.073^{* * *}(0.127)$ & $0.479^{* * *}(0.161)$ & $1.756^{* * *}(0.302)$ & $0.717^{* *}(0.333)$ \\
\hline WROSA & $1.621^{* * *}(0.144)$ & $1.352^{* * *}(0.180)$ & $2.603^{* * *}(0.417)$ & $2.394^{* * *}(0.548)$ \\
\hline LHP & $0.984^{* * *}(0.118)$ & $1.008^{* * *}(0.121)$ & $2.191^{* * *}(0.435)$ & $2.556^{* * *}(0.662)$ \\
\hline BIOC1 & $1.650^{* * *}(0.138)$ & $1.645^{* * *}(0.139)$ & $2.670^{* * *}(0.359)$ & $2.953^{* * *}(0.580)$ \\
\hline BIOC2 & $1.796^{* * *}(0.149)$ & $1.827^{* * *}(0.153)$ & $2.794^{* * *}(0.435)$ & $3.188^{* * *}(0.731)$ \\
\hline \multirow[t]{2}{*}{ AP } & $-0.146^{* * *}(0.028)$ & $-0.157^{* * *}(0.050)$ & $-0.358^{* * *}(0.082)$ & $-0.452^{* * *}(0.129)$ \\
\hline & \multicolumn{3}{|c|}{ Non-attribute variables } & \\
\hline ASC*MALE & & $-0.566^{* *}(0.269)$ & & $-1.757^{*}(0.947)$ \\
\hline WRO*EUT & & $1.372^{* * * *}(0.250)$ & & $2.994^{* * *}(0.898)$ \\
\hline WROSA*EUT & & $0.693^{* *}(0.270)$ & & $1.617^{* *}(0.662)$ \\
\hline \multicolumn{5}{|l|}{ Std.Devs } \\
\hline WRO & & & 0.159 (1.062) & $0.041(0.810)$ \\
\hline WROSA & & & $0.802(0.705)$ & 1.167 (0.808) \\
\hline LHP & & & $3.264^{* * * *}(0.666)$ & $3.874^{* * * *}(1.041)$ \\
\hline BIOC1 & & & $0.667(0.526)$ & $0.724(0.748)$ \\
\hline BIOC2 & & & $0.500(0.962)$ & $0.962(0.947)$ \\
\hline Log likelihood & -650 & -629 & -627 & -602 \\
\hline Pseudo $\mathrm{R}^{2}\left(\rho^{2}\right)$ & 0.260 & 0.280 & 0.434 & 0.456 \\
\hline
\end{tabular}

Table 5. Econometrical results.

Note: ${ }^{* * *},{ }^{* *},{ }^{*}$ Significance at $1 \%, 5 \%, 10 \%$ level. 
mentioned that the international tourists would also like to support local people income from ecotourism while they can enjoy traditional local products and furniture in their hotel rooms.

With highly significant level, the greatest and nonnegative coefficient of both BIOC1 and BIOC2 indicates that the probability of choosing new alternative will increase if the area that hotel takes responsibility for biodiversity conservation increases. However, the probability that a new alternative with BIOC2 will be chosen is greater, there is no completely big difference in value between the coefficients of BIOC2 and BIOC1. As a result, it can be observed that the probability that although a new alternative with 20 ha biodiversity conservation is more likely to be chosen over those with 10 ha; the propensity of increasing in probability is dramatically reduced when the area of conservation moving from 10 to 20 ha. This implies that the area of conservation should be limited in an appropriate scale.

As regards, with interactions MALE in the alternative specific constant and EUT in the attributes WRO and WROSA, the extended MNL in column 2 obtains statistically better than model 1. According to the result of the significant interaction terms, it indicates that explanatory power of model is improved [35]. With larger pseudo R square [29] from 0.260 to 0.280 and highly significantat $1 \%$ level of log-likelihood ratio test, this model also shows highly statistically significant at $1 \%$ level with the same signs of coefficients as in the MNL model forall green attribute variables including price variable, except only the ASC which is inversely positive but not significant however. While the absolutely lower coefficient of WRO and slightly smaller for WROSA and BIOC1 are found, the efficient of AP, BIOC2, LHP and ASC all show larger values, regardless to the signs.

The negative coefficient of MALE variable interacted in ASC implies that female tourist's probability of choosing for new alternative is higher than male tourist's. The positive coefficients of WRO*EUT and WROSA*EUT indicates that the probability that new alternatives will be chosen by European tourist will increase if WRO or WROSA is not excluded from the alternatives. This implies that European tourists are more willing to contribute the efficiency of water use of hotel industry than tourists from other region.

Using Hausman test for IIA by excluding alternative 1 from choice sets [29], the result shows high level of significance at $1 \%$ (Chi-square $(6)=643, \operatorname{Pr}(C>c)=0.000)$. Nevertheless, it is a commonplace to begin with simpler model, like MNL [36], more rigorous specification should be preceded after heterogeneity or IIA violation is detected. While the MNL basically offers an overview of the average preferences and constitutes the benchmark for further analysis [37], the RPL or mixed logit enables to determine possible sources of heterogeneity and is better guided for policies. RPL model in column 3provides the estimates for fitting mixed logit specification by allowing coefficients of attribute variables to vary randomly across respondents with normal distribution, except the price attribute [29] [38]. The model gives statistically better results with log-likelihood -627 and higher pseudo R-square (0.434). As expected, the sign of all attribute variables' coefficients remain the same and highly significant at $1 \%$ but the ASC is positively significant at $10 \%$. In spite of obviously larger coefficients like other studies using mixed logit [38] [39]; the ranking of preference for each green attribute is still the same as the extended MNL model in column 2.

Like the extended MNL, interacting MALE in the ASC and EUT in WRO and WROSA, the result of extended RPL in column 4 shows slightly lower coefficient of WROSA and the same significant level at $1 \%$. But while the coefficient of WRO is lower in magnitude and significant at only $5 \%$, the rest has greater coefficients and the same $1 \%$ level of significance. The coefficient of the ASC is also positive and significant at $5 \%$. Again according to highly significant at $1 \%$ level of log-likelihood ratio test against the RPL model and pseudo Rsquare (0.456), the result of extended RPL model can be statistically superior and more informative. Nevertheless, even the signs of coefficients of all variables remain unchanged; their ranking is different. The coefficient of BIOC2 is still largest and followed by BIOC1and LHP, while WROSA is in the fourth place and lowest for WRO.

In term of interaction, the result of the extended RPL model shows that sign of all interactions' coefficient are still the same as the extended MNL and also the level of significant at $5 \%$ and $1 \%$ for two interactions WRO*EUT and WROSA*EUT. However, lower significant level is found for ASC*MALE at 10\%, these interactions still provide the same information as in extended MNL. Similarly, both coefficient and standard error of all attributes and interaction terms are absolutely changed upward. This confirms the heterogeneous preferences of the international tourists towards the ecologically friendly practices of hotel industry in this Vangvieng Town.

\subsection{Welfare Analysis}

The marginal willingness to pay (MWTP) for one ecofriendly service attribute can be calculated by dividing es- 
timated coefficient on the ecofriendly service attribute of interest by the negative coefficient on the additional price attribute [40].

$$
\text { MWTP }=-\frac{\beta_{i}}{\beta_{p}}
$$

In Table 5, the willingness to pay for one ecofriendly service attribute that related to the river conservation is calculated from the extended RPL model by using the Wald procedure in Nlogit 5 and interaction terms are also taken into accounted [41]. The result shows expectedly that the MWTP for all attribute variables are positively and highly significant at $1 \%$ level, except only the ASC which is also positive but significant at $5 \%$ level (Table 6). The attribute that hotel takes responsibility for 20 ha biodiversity conservation along the river or BIOC2 is the most preferred by respondent with the highest MWTP additional room price for hotel equals to $\$ 7.05 /$ night. Water quality conservation by using wastewater recycling system and serving with organic soaps and amenities or WROSA is ranked as the second preferred attribute with MWTP additional room price equals to $\$ 6.98 /$ night. However, BIOC1, LHP and WRO are ranked as the third, fourth and fifth preferred attributes with MWTP additional room prices equal to $\$ 6.53 /$ night, $\$ 5.65 /$ night and $\$ 4.71 /$ night respectively. It can be observed that the difference between the MWTP for BIOC2 and the MWTP for BIOC1 is lower than $\$ 0.60 /$ night, but nearly \$2.50/night for the difference between WROSA and WRO. Therefore this information should be deliberately considered by both policy maker and hoteliers when those green practices are planning to provide.

The results from the ASC gives the information that without any of these offered green attributes, the respondents have unobservable willingness to pay additional price to support the hotel industry up to $\$ 7.54 /$ night. This can be mentioned that international tourists need hoteliers to participate in carrying of an environment program. In addition, the results from interactions show that European tourists are willing to pay higher additional price for WROSA and RWO than tourists from other regions.

The above mentioned implicit prices do not provide estimates of compensating surplus (CS) for new ecofriendly service alternative scenarios, but welfare measurement can be derived from the marginal rate of substitution between the residual of the initial and alternative utility states divided by the marginal utility of income, which represented by coefficient of "price" attribute [33]. The difference between the welfare measures under the status quo and the alternative scenario are estimated to find the CS associated with each scenario [33]. Let $\beta_{p}$ is denoted the parameter estimate on the price attribute, and $V_{1}, V_{0}$ represent indicative respondents' utility after and before the change under consideration, then, according to Hanemann, 1989 [42], welfare change can be obtained by using CS formula as follow:

$$
\mathrm{CS}=-\left(V_{0}-V_{1}\right) \times 1 / \beta_{p}
$$

In order to estimate the social benefits, the CS can be estimated under the status quo and 2 new ecofriendly service scenarios below:

- Current scenario (status quo): No water quality conservation (no neither only wastewater recycling nor wastewater recycling with organic soaps and amenities), no local handicraft products in guestroom and no biodiversity conservation along the river.

- Scenario 1: Water quality conservation using WRO, local handicraft products in guestroom (LHP), 10 ha biodiversity conservation along the river (BIOC1).

- Scenario 2: Water quality conservation using WROSA, local handicraft products in guestroom (LHP) and 10 ha biodiversity conservation along the river (BIOC1).

Table 6. Marginal willingness to pay additional price for the attribute (\$/night).

\begin{tabular}{ccccc}
\hline \multirow{2}{*}{ Variable } & \multicolumn{2}{c}{ Extended RPL } \\
\cline { 2 - 4 } & Base & EUT & MALE & Weighted MWTP \\
ASC & $9.30^{* *}$ & & $5.42^{* *}$ & $7.54^{* *}$ \\
WRO & $1.59^{* * *}$ & $8.20^{* * *}$ & & $4.71^{* * *}$ \\
WROSA & $5.29^{* * *}$ & $8.86^{* * *}$ & & $6.98^{* * *}$ \\
LHP & $5.65^{* * *}$ & & & $6.53^{* * *}$ \\
BIOC1 & $6.53^{* * * *}$ & & & $7.05^{* * *}$ \\
BIOC2 & $7.05^{* * *}$ & & & \\
\hline
\end{tabular}

Note: ${ }^{* * *},{ }^{* *},{ }^{*}$ Significance at $1 \%, 5 \%, 10 \%$ level. 
- Scenario 3: Water quality conservation using WROSA, local handicraft products in guestroom (LHP) and 20 ha biodiversity conservation along the river (BIOC2).

To estimate overall WTP, it is necessary to include ASC, which captures the systematic but unobserved information about respondent's choices [39].

As regards, the CS for the change from the status quo to the scenarios increases as the levels of ecologically friendly practice of hotel is improved. In Table 7, the mean WTP additional room price for lowest level or scenario 1 is $\$ 17.90 /$ night. But while the WTP additional room price for higher and highest levels of green service or for scenario 2 and 3 equal to \$26.69/night and 27.21/night respectively, the difference of WTP between these scenarios is only $\$ 0.52 /$ night.

\section{Conclusions}

To enhance the sustainable development in ecotourism, the participation of all stakeholders in provision of ecofriendly products and services in tourist sites as well as in tourist town is the most important factor in one hand. On the other hand, customer's behavior and preferences for those green products or services is also a crucial and usually defines what kind of the products should be provided and how much the price should be imposed.

This study on economic evaluation of river conservation towards tourist's preference for ecofriendly services of hotel industry which related to river conservation by using choice experiment valuation technique, the findings from both MNL model and mixed logit model as well as the extended ones show expectedly that all ecofriendly service attributes offered in the survey are significantly preferred by international tourists. Green practice that conserves biodiversity and natural forest along the river within 20 ha or 10 ha are all preferred with the highest and high MWTP for additional room price. This result evidently suggests that the hotel industry in this town should express their responsibility for biodiversity conservation along the river for the sake of their customers' welfare while providing more benefit for environment and gaining more benefit as well as stabilizing their own businesses in the short and long run.

Water quality conservation practice by using wastewater recycling system and serving with organic soaps and amenities or WROSA is more preferred to the practice that only wastewater recycling system or WRO with the difference of MWTP up to $\$ 2.27$. So WROSA is suggested to provide. In addition, the interaction result indicates that European tourists have higher concern on the impact of wastewater from hotel industry on the natural environment in this tourist town while wastewater recycling system can also indeed reduce high level of freshwater demands of hotel industry [30] [31]. Therefore, this green attribute should be strongly considered by the hotelier whose customers are mainly from Europe.

With high value of MWTP, another ecofriendly attribute which should be considered and provided is the service serving with cotton towels, cotton bed sheets and handicraft furniture in guestroom which are handicraft products made by local communities. The preferences towards this attribute of international tourists also links to their willingness to support local communities' income from ecotourism while the can enjoy locally traditional products in their hotel rooms. Also, increasing in benefit from ecotourism will consequently increase the attitudes towards environment conservation of local communities as well [21].

However, the effects of main social-economic demographic factors (income, age and education) which are usually found in many studies on choice are not significantly found. The result of this study provides important information that regardless of income, age and education, those who visit the town are willing to pay for ecologically friendly practices and support the ecotourism of the area while enjoying their stay. Significantly, the finding from gender factor gives a conclusion that female tourists are more receptive to new ecofriendly services. Therefore, appropriate promotion should be considered to increase female tourists.

Table 7. Compensating surplus for each scenario (\$/respondent/night).

\begin{tabular}{cc}
\hline Scenario & Extended RPL Model \\
\hline Scenario 1 & $17.90^{* * *}$ \\
Scenario 2 & $26.69^{* * *}$ \\
Scenario 3 & $27.21^{* * *}$ \\
\hline
\end{tabular}

Note: ${ }^{* * *},{ }^{* *},{ }^{*}$ Significance at $1 \%, 5 \%, 10 \%$ level. 
In addition to providing more detail of market information for sustainable conservation of the Nam Xong River and ecotourism development in this town, preference of domestic tourists and other hotel's customers as well as the participation of hoteliers in provision of good and green services should be properly conducted.

\section{References}

[1] Kamp, U., Binder, W. and Hölzl, K. (2007) River Habitat Monitoring and Assessment in Germany. Environmental Monitoring and Assessment, 127, 209-226. http://doi.org/10.1007/s10661-006-9274-X

[2] Pinto, U. and Maheshwari, B.L. (2011) River Health Assessment in Peri-Urban Landscapes: An Application of Multivariate Analysis to Identify the Key Variables. Water Research, 45, 3915-3924. http://doi.org/10.1016/j.watres.2011.04.044

[3] Green Discovery (2014) Ecotourism Laos. http://www.ecotourismlaos.com/activities/act_river.htm

[4] Department of Tourism Development (2013) Statistic Report on Tourism in Laos. The Ministry of Information, Culture and Tourism, Lao. PDR.

[5] Sosamphanh, B. (2011) Management of Tourism Activities in Vangvieng, Lao PDR, 249-256.

[6] Vangvieng Tourism Office, Statistics Report on Tourism in 2013.

[7] Water Resources and Environment Administration (2008) Stragic Framework for National Sustainable Development Strategy for Lao PDR.

[8] Mekong River Commission (2010) An Assessment of Environmental Impacts of Tourism in the Lower Mekong Basin. MRC Technical Paper, No. 28.

[9] Rogers, P. (2009) Tourism in Vangvieng Strategy for Staying Longer-Spending More. (August).

[10] Environmentally Friendly Hotels (2014) http://www.environmentallyfriendlyhotels.com/

[11] Millar, M. and Baloglu, S. (2011) Hotel Guests’ Preferences for Green Guest Room Attributes. Cornell Hospitality Quarterly, 52, 302-311. http://dx.doi.org/10.1177/1938965511409031

[12] Svensson, P., Rodwell, L.D. and Attrill, M.J. (2012) Hotel Managed Marine Reserves: A Willingness to Pay Survey. Ocean and Coastal Management, 51, 854-861. http://dx.doi.org/10.1016/j.ocecoaman.2008.08.001

[13] Kostakis, I. and Sardianou, E. (2012) Which Factors Affect the Willingness of Tourists to Pay for Renewable Energy? Renewable Energy, 38, 169-172. http://dx.doi.org/10.1016/j.renene.2011.07.022

[14] Kang, K.H., Stein, L., Heo, C.Y. and Lee, S. (2012) Consumers’ Willingness to Pay for Green Initiatives of the Hotel Industry. International Journal of Hospitality Management, 31, 564-572. http://dx.doi.org/10.1016/j.ijhm.2011.08.001

[15] Zander, K.K. and Straton, A. (2010) An Economic Assessment of the Value of Tropical River Ecosystem Services: Heterogeneous Preferences among Aboriginal and Non-Aboriginal Australians. Ecological Economics, 69, 2417-2426. http://dx.doi.org/10.1016/j.ecolecon.2010.07.010

[16] Brox, J.A., Kumar, R.C. and Stollery, K.R. (1996) Willingness to Pay for Water Quality and Supply Enhancements in the Grand River Watershed. Canadian Water Resources Journal, 21, 275-288. http://dx.doi.org/10.4296/cwrj2103275

[17] Ilija, M., Mayer, A.S. and Solomon, B.D. (2007) Economic Valuation of Environmental Services Sustained by Water Flows in the Yaqui River Delta. Ecological Economics, 65, 155-166.

[18] Hanley, N., Wright, R.E. and Alvarez-farizo, B. (2006) Estimating the Economic Value of Improvements in River Ecology Using Choice Experiments: An Application to the Water Framework Directive. Journal of Environmental Management, 78, 183-193. http://dx.doi.org/10.1016/j.jenvman.2005.05.001

[19] Loomis, J., Kent, P., Strange, L., Fausch, K. and Covich, A. (2000) Measuring the Total Economic Value of Restoring Ecosystem Services in an Impaired River Basin: Results from a Contingent Valuation Survey. Ecological Economics, 33, 103-117. http://dx.doi.org/10.1016/S0921-8009(99)00131-7

[20] Dachary-bernard, J. and Rivaud, A. (2013) Ocean and Coastal Management Assessing Tourists' Preferences for Coastal Land Use Management: Oyster Farming and Heritage. Ocean and Coastal Management, 84, 86-96. http://dx.doi.org/10.1016/j.ocecoaman.2013.07.011

[21] Chaminuka, P., Groeneveld, R.A., Selomane, A.O. and Van Ierland, E.C. (2012) Tourist Preferences for Ecotourism in Rural Communities Adjacent to Kruger National Park: A Choice Experiment Approach. Tourism Management, 33, 168-176. http://dx.doi.org/10.1016/j.tourman.2011.02.016

[22] Wang, P. and Jia, J. (2012) Ocean and Coastal Management Tourists’ Willingness to Pay for Biodiversity Conservation and Environment Protection, Dalai Lake Protected Area: Implications for Entrance Fee and Sustainable Management. Ocean and Coastal Management, 62, 24-33. http://dx.doi.org/10.1016/j.ocecoaman.2012.03.001

[23] Petrosillo, I., Zurlini, G., Corlian, M.E., Zaccarelli, N. and Dadamo, M. (2007) Tourist Perception of Recreational En- 
vironment and Management in a Marine Protected Area. Landscape and Urban Planning, 79, 29-37. http://dx.doi.org/10.1016/j.landurbplan.2006.02.017

[24] Pearce, D., Ozdemiroglu, E., Bateman, I., Carson, R.T., Day, B., Hanemann, M., et al. (2002) Economic Valuation with Stated Preference Techniques.

[25] Adamowicz, W., Boxall, P., Williams, M. and Louviere, J. (1998) Stated Preference Approaches for Measuring Passive Use Values: Choice Experiments and Contingent Valuation. American Journal of Agricultural Economics, 80, 6475. http://dx.doi.org/10.2307/3180269

[26] Mitchell, R. and Carson, R. (1989) Using Surveys to Value Public Goods: The Contingent Valuation Method. Resources for the Future.

[27] Hausman, J. and McFadden, D. (1984) Specification Tests for the Multinomial Logit Model. Econometrica, 52, 12191240. http://dx.doi.org/10.2307/1910997

[28] Train, K.E. (2003) Discrete Choice Methods with Simulation. http://dx.doi.org/10.1017/cbo9780511753930

[29] Hensher, D.A., Rose, J.M. and Greene, W.H. (2005) Applied Choice Analysis: A Primer.

[30] Alexander, S. and Kennedy, C. (2002) Green Hotels: Opportunities and Resources for Success Written by Green Hotels.

[31] Deyà, B. and Tirado, D. (2011) Hotel Water Consumption at a Seasonal Mass Tourist Destination. The Case of the Island of Mallorca. Journal of Environmental Management, 92, 2568-2579. http://dx.doi.org/10.1016/j.jenvman.2011.05.024

[32] Zander, K.K. and Garnett, S.T. (2011) The Economic Value of Environmental Services on Indigenous-Held Lands in Australia. PLoS ONE, 6, e23154. http://dx.doi.org/10.1371/journal.pone.0023154

[33] Andreopoulos, D., Damigos, D., Comiti, F. and Fischer, C. (2014) Estimating the Non-Market Benefits of Climate Change Adaptation of River Ecosystem Services: A Choice Experiment Application in the Aoos Basin, Greece. Environmental Science and Policy, 45, 92-103. http://dx.doi.org/10.1016/j.envsci.2014.10.003

[34] Bliem, M., Getzner, M. and Rodiga-laßnig, P. (2012) Temporal Stability of Individual Preferences for River Restoration in Austria Using a Choice Experiment. Journal of Environmental Management, 103, 65-73. http://dx.doi.org/10.1016/j.jenvman.2012.02.029

[35] Albaladejo-Pina, I.P. and Díaz-Delfa, M.T. (2009) Tourist Preferences for Rural House Stays: Evidence from Discrete Choice Modelling in Spain. Tourism Management, 30, 805-811. http://dx.doi.org/10.1016/j.tourman.2009.01.001

[36] Hasler, B., Lundhede, T., Martinsen, L., Neye, S. and Schou, J.S. (2005) Valuation of Groundwater Protection versus Water Treatment in Denmark by Choice Experiments and Contingent Valuation. http://www2.dmu.dk/1 viden/2 Publikationer/3 fagrapporter/rapporter/FR543.PDF

[37] Juutinen, A., Mitani, Y., Mäntymaa, E., Shoji, Y., Siikamäki, P. and Svento, R. (2011) Combining Ecological and Recreational Aspects in National Park Management: A Choice Experiment Application. Ecological Economics, 70, 12311239. http://dx.doi.org/10.1016/j.ecolecon.2011.02.006

[38] Revelt, D. and Train, K. (1998) Mixed Logit with Repeated Choices: Households' Choices of Appliance Efficiency Level.

[39] Birol, E., Karousakis, K. and Koundouri, P. (2006) Using a Choice Experiment to Account for Preference Heterogeneity in Wetland Attributes: The Case of Cheimaditida Wetland in Greece. Ecological Economics, 60, 145-156. http://dx.doi.org/10.1016/j.ecolecon.2006.06.002

[40] Hanley, N., Wright, R.E. and Koop, G. (2002) Modelling Recreation Demand Using Choice Experiments: Climbing in Scotland. Environmental and Resource Economics, 22, 449-466. http://doi.org/10.1023/A:1016077425039

[41] Lourenço-Gomes, L., Pinto, L.M.C. and Rebelo, J.F. (2014) Visitors’ Preferences for Preserving the Attributes of a World Heritage Site. Journal of Cultural Heritage, 15, 64-67. http://dx.doi.org/10.1016/j.culher.2013.01.003

[42] Hanemann, W.M. (1984) Welfare Evaluations in Contingent Valuation Experiments with Discrete Responses. American Journal of Agricultural Economics, 66, 332-341. http://dx.doi.org/10.2307/1240800 